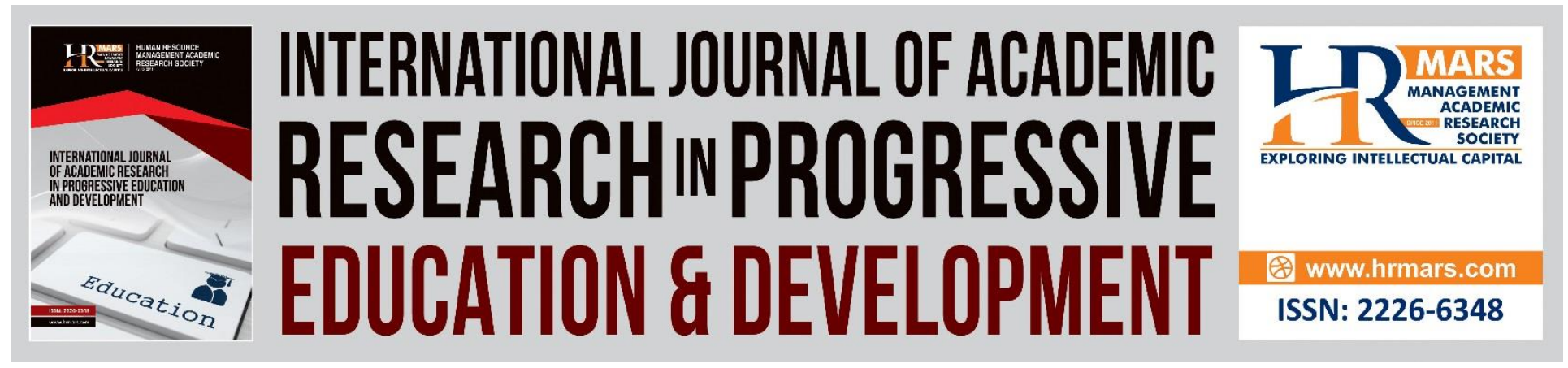

\title{
Learning Style Practised by Students in Andalus Islamic Education Centre, Singapore
}

Zaharuzzaman Sulaiman, Kamarul Azmi Jasmi

To Link this Article: http://dx.doi.org/10.6007/IJARPED/v7-i3/4552

DOI: $10.6007 /$ IJARPED/v7-i3/4552

Received: 03 August 2018, Revised: 18 Sept 2018, Accepted: 23 Sept 2018

Published Online: 10 October 2018

In-Text Citation: (Sulaiman \& Jasmi, 2018)

To Cite this Article: Sulaiman, Z., \& Jasmi, K. A. (2018). Learning Style Practised by Students in Andalus Islamic Education Centre, Singapore. International Journal of Academic Research in Education and Progressive Development, 7(3), 441-452.

Copyright: (C) 2018 The Author(s)

Published by Human Resource Management Academic Research Society (www.hrmars.com)

This article is published under the Creative Commons Attribution (CC BY 4.0) license. Anyone may reproduce, distribute, translate and create derivative works of this article (for both commercial and non-commercial purposes), subject to full attribution to the original publication and authors. The full terms of this license may be seen at: $\underline{\text { http://creativecommons.org/licences/by/4.0/legalcode }}$

Vol. 7, No. 3, July 2018, Pg. 441 - 452

http://hrmars.com/index.php/pages/detail/IJARPED

JOURNAL HOMEPAGE

Full Terms \& Conditions of access and use can be found at http://hrmars.com/index.php/pages/detail/publication-ethics 


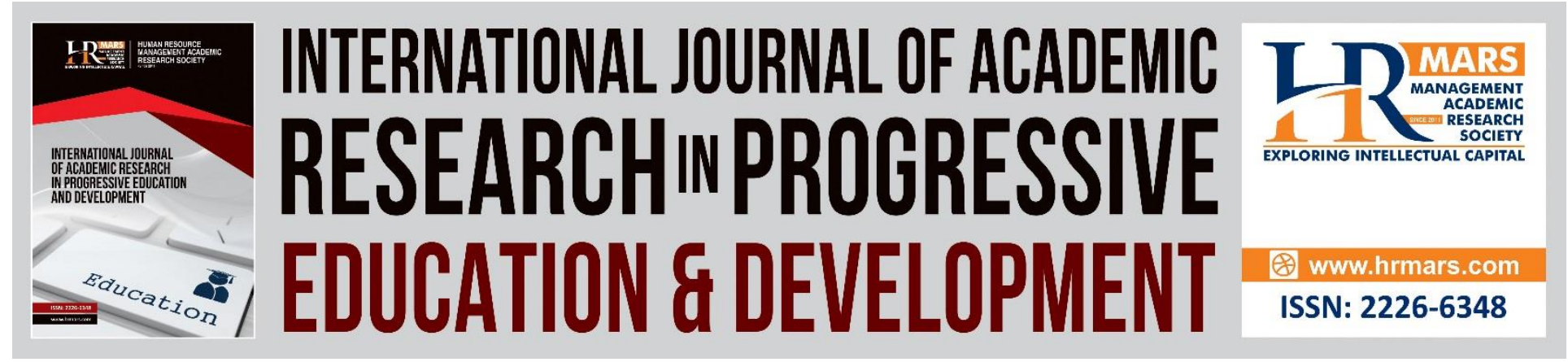

\title{
Learning Style Practised by Students in Andalus Islamic Education Centre, Singapore
}

\author{
Zaharuzzaman Sulaiman ${ }^{1}$, Kamarul Azmi Jasmi² \\ ${ }^{1} \mathrm{PhD}$ Student, Centre for Advanced Studies on Islam, Science, and Civilization (CASIS) \\ Faculty of Social Sciences and Humanities, Universiti Teknologi Malaysia \\ ${ }^{1}$ Senior Executive, Andalus Corporation Pte Ltd (Singapore) \\ ${ }^{2}$ Senior Lecturer, Academy of Islamic Civilization, Faculty of Social Sciences and Humanities \\ Universiti Teknologi Malaysia
}

\begin{abstract}
One of the characteristics of effective learning is the practice of suitable learning style in class. The practice of suitable learning style aims to give students a meaningful teaching and learning experience, thus motivate them to learn. Seeing the importance of this learning style practice, the researcher felt motivated to study the learning style being practised by the students in Andalus Islamic Education Centre (AIEC) as a case study. The result of the questionnaire showed that there is a same tendency of learning style practised by AIEC students. At the end of this paper, several suggestions were put forward to increase the practice of suitable learning style in AIEC.
\end{abstract}

Keywords: Learning Style, Motivation, Islamic Education

\section{Introduction}

The study of religion in Singapore is undertaken as a part time study in as early as a student's life at primary one and more deliberately at the later stages of the academic life of a student. The main reason is Singapore is a secular country and religion is not part of the mainstream curricula. However, this is not the main concerned as students in Singapore can manage their time well to juggle between the two courses of study. The worrying trend is while they are scoring in their conventional schools, they however are performing badly in their religious studies. This study will focus on the learning process which Muslim students have to tackle with the ever-changing methods through the intermingling of both secular and religious subjects. More often the common path taken by religious pedagogy is teacher centric and not student centric (MUIS, 2017).

The process of learning is the lead activity and the utmost important component of education in school (Kamarul Azmi et al, 2015). The implementation and prosecution of education or otherwise depends on the process of learning in and outside class (Azizi \& Nufaizah, 
Vol. 7, No. 3, July 2018, E-ISSN: 2226-6348 @ 2018 HRMARS

2011). One way of assessing the performance of a student's understanding and mastery of knowledge is to know consciously his or her learning style (Zaharuzzaman \& Kamarul Azmi, 2013; Noor Fadhlina \& Kamarul Azmi, 2013).

The learning style will help the student to identify his situational aptitude on learning and henceforth improving on it (Baharin et al, 2007; Kamaruddin et al, 2010). Student who applied a learning style suitable for him or her will achieve a better scoring grade (Bass \& Greary, 1996; Klavas, 1994).

\section{Problem Statement}

Religious study has often played the second fiddle in pursuant to conventional study in this modern time, which implies that priority seems to be misplaced for a Muslim to put and undermined his religious study to second place. However, the case in Singapore is unique, here religious study is pursued both full and part time and this is striving (MUIS, 2017). Albeit this fact, the performance of students in the religious study are below par compared to their score in conventional school. Thus, the main factor for this research is to understand the reason why the same student can performed and scored in the conventional school but underperformed miserably in religious study.

The main contention in education is, it is often equated with academic achievement which itself is not encouraging (Kamarul Azmi, 2010). Henceforth, due attention has to be given to the low academic achievement of students in the AIEC programme. Based on the 2013 report by the Education Division of Andalus (2013), it is found that most students scored lowly in the academic achievement of religious course. The few who were successful scored moderately. This study will help to understand the main reason for this undeserving under performance by the students who at another spectre can score well in their conventional school.

There are few contributing factors to the differential in score such as the background of the students and their intellectual capacity. There are other intermidating factors such as the learning styles and student level of motivation. According to Meor Ibrahim and Assaadah (2011), the learning styles of each student is important as it has a strong influence in the academic outcome and mandated a correct mechanism that challenges the student ability simultaneously providing a guided feedback of their achievements. This will be the focus of the study.

The different aspects and styles of learning among students must be investigated to explore and match the learning styles with the process of learning of each student. A significant portion of the students is affliciated with a learning style that is dominant. There are also students who applied multiple approaches of learning styles in their learning methods and processes. However there are still a number of students who struggled to adapt and apply a strategic learning style which compliment their learning methods. The resultant effect is they do not score well in their academic achievements. This is infact due to the wrong application of learning style that is neither unapplicable nor effective in their learning. (Abdullah, 2011). From here, the reseacher will extract a possible solution in the case of mediocre performance of students in AIEC programmes.

As findings from past research (Norlia et al, 2006; Baharin et al, 2007; Mohd. Nor \& Hazwani, 2007) has shown a significant achievement in studies when the learning style matched with the learning activity. Their research elucidated that students who engaged in learning style that suited with their learning scored better. 
Vol. 7, No. 3, July 2018, E-ISSN: 2226-6348 @ 2018 HRMARS

In brief, to sum up the problem statement as the teaching methods of the teachers are unsuitable with the learning methods or styles of the students of AIEC, compounded by the students, themeslves too are confused and unable to manage properly the learning stlye that suits them. The effects of this mismatched and misunderstanding about the learning style between the teacher and student resulted in a student being less motivated. Consequently the student performance plunged (Fathurrahman, 2013). Consecutively, a study on the learning style is employed in order for teacher to better understand the learning style that is suitable and proper in accordance with the learning style of the students.

\section{Literature Review}

Nor Zakiah (2010) stated, style includes behaviourals, designs or methods. Consequently learning style of a person refers to the ways or methods of learning. In education physcology's nuances, the learning style indicates the methods a student channelling his focus and reciprocal actions, all to process and obtain information, data on new knowledge and experience.

Psycologists from the school of cognitive indicate the learning style is the thought processes under the realm of perception and processing information to formulate concept and principle. According to Suppiah et al (2012), learning style is the most liked method by a student. Besides, learning style implicates to the condusive environment in which a student learnt in the most optimum conditions. Mok (2010) elaborates learning style as a way the five determinants - the environment, emotion, social, physiology and psychology catapult the individual capabilities to understand, interact and response to the learning environment. Kamarudin (2010) defines learning style as a set of guided actions manifested by the individual extracting his mental ability to interact with the environment, then collate and process the needed information. Kamarudin reiterates each individual is born with a unique and precise learning style. Both herediatery and environment plays an important part of a leering style of that individual. Baharom \& Iliyas (2010) intertwined personal or personality with the learning style and concluded that students have different personality concurrent with their multitudes of learning methodologies.

The knowledge on the different learning style of each student is important in order that teachers are most sensitive toward these differences that exist amongst the students. These aspects of learning styles are pertinent as it guides the teachers to create a learning environment and experience that concurs with how their students study (Nor Zakiah, 2010). Now if this happens, when the teacher manages to create the ambience of learning that coincide and is suitable with the learning style of the students - this will facilitate the study process and the student may be more effective in learning. Alternatively if the opposite happens that a teacher is unable to create a syimbiotic relationship between the learning methods and the learning style of a student, this will result in a student's underachieving academic result.

In brief, the learning style may be summarized as a way or methodology a student focuses to process, interpret and acquire information, knowledge, skills or new experiences or formulate a concept and principle.

\section{Research Objectives}

The research objectives are derived based on the research theory. The researcher strives to achieve three objectives build upon this research. They are: 
(1) To identify the different derivatives of learning styles practice by the students of AIEC during the teaching and learning sessions in class.

(2) To identify the different level of motivation of the students of AIEC during the teaching and learning sessions in class.

(3) To deduce the relationship between the level of motivation of the students of AIEC and their differential learning styles during the teaching and learning sessions in class.

From these objectives, this research will attempt to answer the nil hypothesis of the research, that is:

$\mathrm{H}_{01} \quad$ There is no significant relationship between AIEC students' motivation and their learning styles during the teaching and learning sessions in class.

\section{Research Validity}

The research validity is authenticated by face and content validity instruments - through research questions formulated with the cooperation of secondary three students and their teacher-incharge. In addition to this, the input and validation of four experts in Islamic Education from various institutions were sought. Content validity questionaires were constructed through a pilot study. This pilot study was undertaken in one of the branches of Andalus Education Center with 37 respondents from the secondary 3 student population. The result of Alfa analysis proved the learning style contruction reached a level of 0.92 reliability which is significantly high, while motivational construction reached a high level of 0.73 (George \& Mallery, 2003).

\section{Research Findings and Discussion}

The research findings based on background analysis of correspondents revealed that of the 108 students, $55.6 \%$ are male (boys) and the remaining $44.4 \%$ are female (girls). From these 108 students, $21.4 \%$ respondents consist student from AIEC 1, 29.6\% are from AIEC 2, 30.5\% are AIEC 3 students and the rest $15.7 \%$ of the respondents are from AIEC 4 .

In this research, the researcher utilized the interpretation table of Abdull Sukor et. al. (2008) as shown in Table 1 to extract a simple figurative explanation about the level of learning styles and motivation of the student under this study.

Table 1 Interpretation of Mean Score

\begin{tabular}{ll}
\hline Mean Score & Interpretation \\
\hline $3.01-4.00$ & High \\
\hline $2.01-3.00$ & Moderate \\
\hline $1.00-2.00$ & Low \\
\hline
\end{tabular}

(Abdull Sukor et. al., 2008)

The research focuses on three styles of learning namely visual, auditory and kinestetic learning styles. These are further breakdown according to AIEC students' perception to obtain a minimum score which is arranged in a descending order of a highest score to a lowest score. Based on Table 2, the overall mean score of the learning style of AIEC students is moderate with 
INTERNATIONAL JOURNAL OF ACADEMIC RESEARCH IN PROGRESSIVE EDUCATION AND DEVELOPMENT

Vol. 7, No. 3, July 2018, E-ISSN: 2226-6348 @ 2018 HRMARS

a mean score 2.74 . The findings too, reflected the level of the three learning styles is moderate with the resultant breakdown of kinesthetic learning style (mean 2.82) was more dominant compared to the learning styles of auditory (mean 2.73) and visual (mean 2.66) (see Table 2).

Table 2 Mean and Standard Deviation Learning Style of AIEC Students

\begin{tabular}{lll}
\hline Learning Stye & Mean & SD \\
\hline Kinesthetic & 2.82 & 0.75 \\
Auditory & 2.73 & 0.77 \\
Visual & 2.66 & 0.77 \\
\hline Overall Mean & $\mathbf{2 . 7 4}$ & $\mathbf{0 . 7 6}$ \\
\hline
\end{tabular}

Further the finding shows that the usage of kinesthetic and auditory can be further dissected into 2 levels or categories, first the high score and second moderate score. Whilst, visual learning style is further divided into 3 levels of usage - high, moderate and low. The high score of the kinaesthetic learning style demonstrates that the AIEC students 'likely to remember what they experienced' (mean 3.31), 'love to study by doing an activity in class' (mean 3.19), 'enjoy class when doing experiment' (mean 3.15), 'likely to remember thing they did' (mean 3.13), 'study better if there is an activity in class' (mean 3.06), and 'study more better in class if they took part in the related activity' (mean 3.01) (see Table 3).

Table 3 Mean Score Kinesthetic learning Style and Standard Deviation of AIEC student with High Score

\begin{tabular}{lcl}
\hline Kinesthetic Learning Style of AIEC students & lean & SD \\
\hline I strongly remember things I experienced & 3.31 & 0.52 \\
\hline I enjoy learning hand-on in class & 3.19 & 0.64 \\
\hline I enjoy learning through conducting experiments in class & 3.15 & 0.76 \\
\hline I strongly remember things I done & 3.13 & 0.67 \\
\hline If I do some activity in class, I learn better & 3.06 & 0.57 \\
\hline I study more better in clas if I took part in the related activity & 3.01 & 0.69 \\
\hline
\end{tabular}

Furthermore, the usage of kinesthetic learning style at the moderate level as shown in Table 4 commensurate with AIEC student 'always saying, "I know how you feel" in a conversation' (mean 2.85), 'keen to imagine oneself as the character of book they read' (mean 2.81), 'likely to loose concentration in class when idle for 30 minutes' (mean 2.77), 'always fidgeting with things on their desk in class' (mean 2.48), 'understand better in class when taking part in a role-play' (mean 2.47), 'keen to take notes when a new subject material is introduced' (mean 2.31), and 'likely to act a scene in order to remember the details of a story' (mean 2.14). 
INTERNATIONAL JOURNAL OF ACADEMIC RESEARCH IN PROGRESSIVE EDUCATION AND DEVELOPMENT

Vol. 7, No. 3, July 2018, E-ISSN: 2226-6348 @ 2018 HRMARS

Table 4 Mean Score Kinesthetic Learning Style and Standard Deviation of AIEC Students with Moderate Score

\begin{tabular}{lll}
\hline Kinesthetic Learning Style of AIEC students & Mean & SD \\
\hline During a conversation, I always say: “I know how you feel." & 2.85 & 0.83 \\
\hline When reading a book, I am inclined to imagine I am the character & 2.81 & 0.95 \\
\hline I lost focus in class when I sit still for more than 30 minutes & 2.77 & 0.92 \\
\hline In class, I am always fidgeting with the things on my desk & 2.48 & 0.79 \\
\hline I understand the subject matter when I took part in the role play & 2.47 & 0.77 \\
\hline When given a new subject material, I am inclined to take notes & 2.31 & 0.85 \\
\hline When remembering the details of a story, I am most likely to act & & \\
the story & 2.14 & 0.74 \\
\hline
\end{tabular}

While the usage of auditory learning style shows at the high level means that AIEC students 'learn better if they were told to perform certain task' (mean 3.33), 'understand well when a teacher gives instruction' (mean 3.29), 'learn better when a teacher gives explaination' (mean 3.02), and 'learn better if they listen from someone' (mean 3.01) (See Table 5).

Table 5 Mean Score Auditory Learning Style and Standard Deviation of AIEC Students with High Score

\begin{tabular}{lll}
\hline Auditory Learning Style of AIEC Students & Mean & SD \\
\hline I learn better when there is someone to tell how to do it & 3.33 & 0.66 \\
\hline When a teacher gave instruction, I understand better & 3.29 & 0.53 \\
\hline I learn better when the teacher explained & 3.02 & 0.81 \\
\hline I learn better if I heard from someone & 3.01 & 0.73 \\
\hline
\end{tabular}

The constant used of auditory learning style at the moderate level as shown in Table 6 witnessed that AIEC students 'strongly remember things they heard' (mean 2.98), 'keen to hear my own voice in my mind when reading a book' (mean 2.94), 'better understand lesson heard in class' (mean 2.92), 'strongly remember what was being said' (mean 2.78), 'like to hear a story when remembering the details of the story' (mean 2.75), 'easily distracted in class when hearing something outside' (mean 2.55), 'likely to discuss aloud with other students when given new lesson material' (mean 2.26), 'always say, "I heard what you said" in a conversation' (mean 2.22), 'likely to discuss aloud alone when given new lesson material' (mean 2.1), and 'always sing to myself when in class' (mean 2.09). 
INTERNATIONAL JOURNAL OF ACADEMIC RESEARCH IN PROGRESSIVE EDUCATION AND DEVELOPMENT

Vol. 7, No. 3, July 2018, E-ISSN: 2226-6348 @ 2018 HRMARS

Table 6 Mean Score Auditory Learning Style and Standard Deviation AIEC Students with Moderate Score

\begin{tabular}{lll}
\hline Auditory Learning Style of AIEC students & Mea & SD \\
& n & 0.6 \\
I am likely to remember what I heard & 2.98 & 4 \\
\hline When reading a book, I am inclined to listen to my own voice in my mind & 0.8 \\
& 2.94 & 7 \\
\hline I remember better thing I heard in class & 0.6 \\
\hline & 2.92 & 6 \\
\hline I strongly remember thing I said & 0.6 \\
\hline When recalling the details of a story, I love to listen to the story & 2.78 & 3 \\
\hline & 0.9 \\
I am easily distracted in class when I hear something outside & 2.75 & 2 \\
\hline When given new lesson material, I am inclined to discuss loudly with other & 0.8 \\
students & 2.55 & 7 \\
\hline & 2.26 & 2 \\
\hline In a conversation, I always say: “I heard what you said." & 0.8 \\
\hline When presented with a new subject material, I am inclined say it aloud to & 2.22 & 7 \\
myself & 2.1 & 0.8 \\
\hline In class, I always sing to myself & 1.0 \\
\hline
\end{tabular}

Whilst the usage of visual learning style with a high score shows that the AIEC students are 'keen to play the scene in their minds from a story they read' (mean 3.41), 'likely to read again when remembering details of the story' (mean 3.1), 'strongly remember things I saw' (min 3.09), and 'better understanding by reading instructions' (mean 3.03) (See Table 7).

Table 7 Mean Score Visual Learning Style and Standard Deviation AIEC student with High Score

\begin{tabular}{lll}
\hline Visual Learning Style of AIEC Students & Mea & SD \\
\hline When reading a book, I am inclined to act the scene on my mind & $\mathbf{n}$ & \multicolumn{1}{l}{0.7} \\
\hline When remembering the details of a story, I am likely to re-read the story & 3.41 & 2 \\
\hline & 3.1 & 7 \\
\hline & & 0.6 \\
I strongly remember things I saw & 3.09 & 2 \\
\hline & & 0.5 \\
I understand better when reading the instructions & 3.03 & 9 \\
\hline
\end{tabular}




\section{INTERNATIONAL JOURNAL OF ACADEMIC RESEARCH IN PROGRESSIVE EDUCATION AND DEVELOPMENT}

Vol. 7, No. 3, July 2018, E-ISSN: 2226-6348 @ 2018 HRMARS

Subsequently, the usage of visual learning style at the moderate level as reflected in Table 8 shown that AIEC students 'learn better by reading what was written by the teacher on the whiteboard' (mean 2.92), 'strongly remember materials they read' (mean 2.81), 'remember better by reading it' (mean 2.81), 'learn better by reading' (mean 2.69), 'always say, "I see what you meant" in a conversation' (mean 2.6), 'easliy distracted in class when seeing something outside' (mean 2.58), 'most likely to see the words in their minds when reading a book' (mean 2.57), 'learn better by reading the lesson material rather than listening to the teacher' (mean 2.56), 'always scribbling in class' (mean 2.42), dan 'always draw in class' (mean 2.22).

Table 8 Mean Score Visual Learning Styles and Standard Deviation AIEC Students with Moderate Score

\begin{tabular}{lll}
\hline Visual Learning Style of AIEC Students & Mea & SD \\
& $\mathbf{n}$ & 0.6 \\
\hline I learn better by reading what was written on the whiteboard by the teacher & 2.92 & 7 \\
\hline & & 0.7 \\
I strongly remember what I read & 2.81 & 8 \\
\hline & & 0.6 \\
If I read the instructions, I recall better & 2.81 & 6 \\
\hline & & 0.7 \\
I learn better through reading & 2.69 & 6 \\
\hline In a conversation, I always say: “I see what you mean." & 0.8 \\
\hline I am easily distracted in class when I saw something outside & 2.6 & 5 \\
\hline When reading a story book, I am inclined to see the words in my mind & 0.9 \\
\hline I learn better by reading the textbook than listening to the teacher & 2.58 & 3 \\
explaination & 2.57 & 8 \\
\hline & 2.56 & 8 \\
\hline In class, I always scribble something & & 0.7 \\
\hline In class, I always draw & 1.0 \\
\hline
\end{tabular}

The last category or the least used or to be précised this visual learning style is never practised or used by AIEC students is 'drawing a diagram when a new subject material is introduced' (mean 1.93) and 'drawing a chart when a new subject material is introduced' (mean 1.86) (See Table 9). 
INTERNATIONAL JOURNAL OF ACADEMIC RESEARCH IN PROGRESSIVE EDUCATION AND DEVELOPMENT

Vol. 7, No. 3, July 2018, E-ISSN: 2226-6348 @ 2018 HRMARS

Table 9 Mean Score Visual Learning Style and Standard Deviation of AIEC students with Low Score

\begin{tabular}{lll}
\hline Visual learning style of AIEC students & Min & SD \\
\hline When introduced to new subject material, I am keen to draw a diagram & 1.93 & 0.73 \\
\hline When indtroduced to new subject material, I am keen to draw a chart & 1.86 & 0.72 \\
\hline
\end{tabular}

Overall the motivational level of students showed that AIEC students are moderately motivated. The finding shows an overall mean score of AIEC students motivation is 2.73 (See Table 10).

Table 10 Mean Score Motivation and Standard Deviation of AIEC students

\begin{tabular}{lll}
\hline Motivation & Mean & SD \\
\hline Intrinsic & 2.79 & 0.75 \\
Exstrinsic & 2.66 & 0.75 \\
\hline Overall Mean & $\mathbf{2 . 7 3}$ & $\mathbf{0 . 7 5}$ \\
\hline
\end{tabular}

Table 11 Correlation of Learning Style and Motivation of AIEC Students

\begin{tabular}{llll}
\hline & & $\begin{array}{l}\text { Student } \\
\text { Motivation }\end{array}$ & $\begin{array}{l}\text { Students } \\
\text { Styles }\end{array}$ \\
\hline Students Motivation & $\begin{array}{l}\text { Pearson } \\
\text { Correlation }\end{array}$ & 1 & $.540^{* *}$ \\
\cline { 2 - 4 } & Sig. (2-tailed) & \multicolumn{1}{c}{ Learning } \\
\cline { 2 - 4 } & $\mathrm{N}$ & 108 & 108 \\
\hline Students Learning Styles & $\begin{array}{l}\text { Pearson } \\
\text { Correlation }\end{array}$ & $.540^{* *}$ & 1 \\
\cline { 2 - 4 } & Sig. (2-tailed) & .000 & 108 \\
\cline { 2 - 4 } & $\mathrm{N}$ & $108 \quad$ **Significant Correlation Level at
\end{tabular}

0.01 ( 2 ends)

The study also scrutinised the level of relationship between the learning styles toward the AIEC students' motivation. Nil hypotesis of the study is invalidated as there is a significant correlation at the high score between the learning styles and student motivation with a score $r=$ 0.540 (See Table 11). This according to Pallant (2007) that the score $r$ at a level of 0.50 to 1.00 shows a significant correlation at the high score (See Table 12).

Table 12 Correlation Indicator by Pallant (2007)

\begin{tabular}{ll}
\hline Indicator & Score $\boldsymbol{r}$ \\
\hline High & $0.50-$ \\
Moderate & 1.00 \\
Low & $0.30-$ \\
& 0.49 \\
& $0.10-$ \\
\hline
\end{tabular}

Pallant (2007) 


\section{Discourse and Implication}

Generally, the research has shown that the application of learning style of students of AIEC is moderate and the most dominant learning style adopted by the students is kinesthetic. This style proved that students of AIEC learnt productively through experience and active involvement in the lesson activities. The result concurs with Gohel K.D. (2009) that experience and active involvement in class help student to recall what they were taught in class autonomously answering examination questions hence improving their performance.

The research findings too elucidate that the achievement level of AIEC students is moderate and the dominant motivational style is that of intrinsic motivation. This is explained by the strong build-in encouragement of students to learn the subject matter related to Islamic studies. This is concurrent with Mok (2011) who opined that intrinsic motivation spurred from an internal drive in a student to be involved in the process of learning.

Furthermore, the findings too reveal there is a significant relationship at the high score level between the learning style and AIEC student's motivation. This concurs with the research findings of Norlia et. al. (2006) and the findings of Rajshree (2013). Research of Norlia et. al. (2006) shows that effective learning styles when employed concurrently with a high level of motivation will result in an increased in students performance and achievement. Whilst, the research of Rajshree (2013) proves that a concrete learning style will facilitate a student to an improved achievement. Eventually this is more effective when learning style of a student is fuelled by the student's motivation.

Learning style is an important contributing factor on the variation of the achievements (Baharin et al, 2007). The strong symbiotic relationship between learning style and motivation reflected the value place on both variables which is directly proportional to achievement. This conclusive evidence stressed and reiterated the importance to focus on the learning styles and motivation of the students as an effort to stir them to an improved and increased performance in their study. However having a highly motivated student is inadequate if he does not master or has a high skill on learning style simultaneously it is just not enough to have the necessary learning style is he is not highly motivated. It simply does not necessarily equate as such.

\section{Conclusion}

The study places an important relationship which is directly proportional between learning style, motivation and students' performance. Both teachers and students have to play their parts in order to produce result in term of students' performance. However, emphasis now is placed on the student to have the desire and zeal to succeed. Since the usage of learning style is moderate there must be a concerted effort to improve this score to the higher end.

It is pertinent that not only the student has to manage and decide the optimum learning style suitable for him or her to achieve the desirable result but coherently the teachers too must understand the learning style of the student to adapt the teaching and learning methodology and marries it with the different learning styles of the students. Thus not only that AIEC has to employ the method best suited for most students which is kinesthetic but also auditory and visual to have a higher impact on learning.

From the findings of this research, any deficiency and lack of usage to employ the correct learning styles must be addressed by both students and teachers of AIEC in order to improve the 
Vol. 7, No. 3, July 2018, E-ISSN: 2226-6348 @ 2018 HRMARS

pedagogy and learning techniques to be dynamic and progressive and seriously reflecting the true status and stature of Islamic studies. In this aspect motivation plays a pivotal role. Intrinsic motivation has to be deployed at all level to achieve maximum effects. Furthermore the researcher felt that in case of Islamic study the intangible benefits of learning Islam must be incorporated to trigger the sense of being a better person. Academic result is important but it must work concurrently with faith to produce a practicing Muslim.

\section{Suggestions}

From the research findings, few suggestions to improve and reduce the differential gap on the constant usage of learning styles of AIEC students in order that the motivational level of students remain significantly high towards the teaching and learning of Islamic Education. Among them are:

(1) Students are required to identify their unique learning styles through consulation with their school counsellor or Guidance and Counselling Unit of each individual school.

(2) Students are informed and guided on the importance of learning styles in respect to their learning processes.

(3) Teachers are to improvise various teaching techniques, approaches to lession, teaching and learning materials and create activities to inspire student to their optimum learning level.

(4) Teachers are to maintain a high level of professionalism in coaching, tutoring, supporting and motivating students.

(5) Teachers are to evaluate and explore the student's attitude and keenest toward studies periodically from time to time.

(6) Teachers are to create a lively and cheerful learning ambiance and surrounding and stimulate the student in accordance with the apptitude and ability towards study.

(7) Teachers are to improve the quatily of teaching materials suitable with the learning styles of student for the particular subject.

(8) School counsellor and guidance teacher are to maintain and help to upkeep a proper record to identity the learning styles of students.

(9) Parents are to instill the importance and need of their child to be independent and responsible learner to face the ever changing education landscape from time to time.

(10) Parents are to give full support towards school in fulfilling the requirement of their child educational needs.

(11) Parents are to provide the physical needs of their child to compliment the learning style of their child.

The tripartite alliances and cooperation of students, teachers and parents must be pro-active advance to create an opportunity to operate and scrutinize the suggestions of this research for the benefits and advancement of Islamic Study. These three components must simultaneously take heeds of the findings of this research. 
INTERNATIONAL JOURNAL OF ACADEMIC RESEARCH IN PROGRESSIVE EDUCATION AND

DEVELOPMENT

Vol. 7, No. 3, July 2018, E-ISSN: 2226-6348 @ 2018 HRMARS

\section{References}

Abd. Aziz, N., M. Meerah, T.S., Halim, L., \& Osman, K. (2006). Hubungan Antara Motivasi, Gaya Pembelajaran Dengan Pencapaian Matematik Tambahan Pelajar Tingkatan 4. Jurnal Pendidikan 31. 123-141.

Abdul Ghafar, M.N. (1999). Penyelidikan Pendidikan. Johor Bahru: Penerbit Universiti Teknologi Malaysia.

Abu, B., Md Johan, O., Syed Mansor, S.M.S. \& Jaafar, H. (2007). Kepelbagaian Gaya Pembelajaran dan Kemahiran Belajar Pelajar Universiti di Fakulti Pendidikan, UTM Johor. Research Vote No: 71881. Universiti Teknologi Malaysia.

Al-Ghazali, al-Imam Abu Hamid Muhammad ibn al-Ghazali. (2004). Ihya' 'ulum al-din. Jil. 1-5. AlQahirah: Dar al-Afaq al-'Arabiyah.

Barbe, W. B., \& Swassing, R. H. (1979). Teaching through modality strengths: Concepts and practices. Columbus: Zaner-Bloser.

Bass, G.M. \& Greary, W.T. (1996). Education Research Abstracts. Accounting Education, (1), 238242.

Bogdan, R.C. \& Miklen, S.K. (2003). Qualitative Research for Education: An Introduction to Theory and Methods. Boston: Allyn \& Bacon.

Cohen, L., Manion, L. \& Morrison, K. (2000). Research Methods in Education. Fifth Edition. London: Routledge Falmer.

Dawoed, F., (2013). Feb 2013 Temu Bual Bersama Fathurrahman Dawoed, Pengarah Eksekutif Divisyen Pendidikan.

Divisyen Pendidikan Andalus (2013). Keputusan Peperiksaan Bersama Pendidikan Agama Menengah 4 Tahun 2010-2012.

Dunkin, M.J. \& Biddle, B.J. (1974). The Study of Teaching. New York: Holt, Renehart, and Winston. George, D., \& Mallery, P. (2003). SPSS for Windows Step by Step: A Simple Guide and Reference. 11.0 Update. 4th ed. Boston: Allyn \& Bacon.

Gohel, K.D. (2009). The Effect of Learner's Learning Style Based Instructional Strategy on Science Achievement of Secondary School Students. Thesis PhD. Saurashtra University.

Hj. Husin, K. (2011). Psikologi Pembelajaran. Kuala Lumpur: Utusan Publications \& Distributors Sdn. Bhd.

Ilias, K., Abdul Rahman, R., Md Noor, M., \& Saidon, N.A. (2010). Pengaruh Gaya Pembelajaran Terhadap Motivasi dan Pencapaian Akademik Pelajar Pra ljazah Sarjana Muda Perguruan Institut Pendidikan Guru Kampus Ipoh. Jurnal Penyelidikan Dedikasi Jilid 2.

Jasmi, K.A. (2010). Guru Cemerlang Pendidikan Islam Sekolah Menengah di Malaysia: Satu Kajian Kes. (PhD), Universiti Kebangsaan Malaysia, Bangi, Selangor. Available from http://dms.library.utm.my:8080/vital/access/manager/Repository/vital:67877

Jasmi, K.A., Zawawi, A., \& Masrom, S.F. (2015). "Students and School Learning Environment Motivate Success of Excellent Islamic Education Teachers (EIET)". TAMU, 2(1), 83-92.

Klavas, A. (1994). Learning style program boosts achievement and test scores. Clearing House, 67(3), 149.

Mohamad, B. \& Hashim, I. (2010). Gaya Pengajaran \& Pembelajaran. Selangor: PTS Professional Publishing Sdn. Bhd 
INTERNATIONAL JOURNAL OF ACADEMIC RESEARCH IN PROGRESSIVE EDUCATION AND DEVELOPMENT

Vol. 7, No. 3, July 2018, E-ISSN: 2226-6348 @ 2018 HRMARS

Mok, S. S. (2010). Psikologi Pendidikan untuk Pengajaran \& Pembelajaran. Edisi Kedua. Selangor: Penerbitan Multimedia Sdn. Bhd.

Mok, S. S. (2011). Psikologi Pendidikan. Edisi Kedua. Selangor: Penerbitan Multimedia Sdn. Bhd.

Nachiappan, S., Kamaruddin, K., Abd. Shukor, A.A., Jantan, R., Mustapha, R., \& Hamzah, H. (2012). Pembelajaran dan Perkembangan Pelajar. Edisi Kedua. Selangor: Oxford Fajar Sdn. Bhd.

Nawawi, N. F. \& Jasmi, K. A. (2013), 26 Jun 2013. Hubungan antara Pengajaran dan Pembelajaran $(P \& P)$, Keperibadian serta Kemahiran Guru Pendidikan Islam dengan Motivasi Pelajar. Kertas Kerja dalam Seminar Pasca Siswazah Pertama. Fakulti Tamadun Islam. The Main Hall, Faculty of Islamic Cilization, Universiti Teknologi Malaysia.

Pallant, J. (2007). SPSS Survival Manual. Australia: Ligare Book Printer Sydney.

Shaari, A.S., Yusof, A.A., Jamal Khan, M.K., Tang, S. M. \& Lim, K. T. (2008). Keadilan Penilaian Prestasi dalam Kalangan Guru dan Hubungannya dengan Motivasi Kerja dan Prestasi Akademik Sekolah. International Journal of Management Studies (IJMS), 15. pp. 159-176.

Sulaiman, Z., \& Jasmi, K.A. (2013) 26 Jun 2013. Gaya Pembelajaran dan Hubungannya dengan Motivasi Pelajar: Satu Kajian Tinjauan di Pusat Pendidikan Andalus Peringkat Menengah di Singapura. Kertas Kerja dalam Seminar Pasca Siswazah Pertama. Fakulti Tamadun Islam. Main Hall, Faculty of Islamic Cilization, Universiti Teknologi Malaysia.

Umar, N.Z. (2010). Kaedah Pengajaran Ibadah Tahun Satu Fokus Kepada Istinjak. Proceedings of International Conference on Islamic Education (ICIEd 2010). Bandar Baru Bangi: Persatuan Intelektual Muslim Malaysia.

Vaishnav, R.S. (2013). Learning Style and Academic Achievement of Secondary School Students. Voice of Research Vol. 1 Issue 4.

Yahaya, A. \& Abd. Majid, N. (2011). Hubungan Antara Budaya Formal Sekolah Dan Gaya Pembelajaran Pelajar Dengan Pencapaian Akademik Pelajar Sekolah Menengah. Journal of Educational Psychology and Counseling, Volume 2, Jun 2011, Pages 78-112

Zakaria, A. (2011). Pengajaran dan Pembelajaran Berasaskan Pendekatan Berpusatkan Pelajar dalam Pendidikan Islam di Sekolah Menengah Kebangsaan. (Doktor Falsafah), Universiti Kebangsaan Malaysia, Bangi, Selangor. 